\title{
Die invloed van skielike verwestersing op die gesondheid van die Boesmanvolk
}

Daar was waarskynlik nog nooit in die geskiedenis van die wêreld 'n volk wat so plotseling oorgeplaas is van ' $n$ uiters primitiewe bestaan na die wonders, en gevare, van die moderne wêreld as die Boesmans in S.W.A. nie. Dit het plaasgevind met die ontstaan van 'n oorlogsituasie in daardie gebied toe groot getalle van hulle gewerf is om diens te doen in die Weermag, waar hulle uitnemende spoorsnyers is. Hulle het dus, met hul gesinne, die tradisionele Steentydperkbestaan verlaat en by die Weermagbasisse kom woon en baie vinnig ' $n$ Westerse leefwyse en ook eetpatroon aanvaar.

Sommige basisse, soos Omega, is reeds etlike jare gevestig, terwyl ander nuwer is en daar is dus vandag in Suidwes verskillende groepe Boesmans met variërende tydperke en grade van blootstelling aan 'n Westerse leefwyse en eetgewoontes.

Ons Instituut het in hierdie situasie van veranderende leefwyse nog een van die besondere geleenthede vir navorsing, wat eenmalig en uniek aan SuiderAfrika is, gesien en 'n poging aangewend om sekere waarnemings by die verskillende groepe te maak, met die oog op moontlike meegaande veranderings in hul gesondheid.

Die S.A. Weermag en die S.A.G.D. het dit vir ons moontlik gemaak om gedurende 1983, met behulp van 'n dienspligtige geneesheer en Boesmansoldate as gidse, verskeie groepies Boesmans te besoek en beperkte waarnemings te maak. Ons was noodwendig weens die tyd en gebrek aan fasiliteite beperk tot basiese waarnemings en het ons gegewens met groot moeite en heelwat avontuur bekom.

Die groepe wat ons besoek het, woon verspreid in die gebied Suidoos van Grootfontein verby die Noma Omavamba tot aan die grens van Botswana en kan verdeel word in baie primitiewe tot gedeeltelik verwesterse groepe, van die Kimbobewoners in die veld tot dié by die nuwer basisse, en dan die heel verwesterse groep by Omega.

Inligting oor eetgewoontes en leefwyse is vlugtig verkry en dit word vir ons aangevul deur waarnemings van medewerkers wat ons in die gebied ontmoet het. Ons kon basiese waarnemings ten opsigte van massa, lengte, bloeddruk en polsspoed maak en kon bloed vir biochemiese toetse verkry.

Daar het ook intussen uit persoonlike kommunikasie met prof. Trefor Jenkins ongepubliseerde data uit sy vroeëre besoeke in 1971 en die van Kaminer in 1959 in sekere areas in die gebied aan die lig gekom. Dit het gehelp om die uiters skrale inligting in die bestaande literatuur oor die Boesmans aan te vul en ons het dit gebruik om die oorspronklike toestand van die Boesmans te probeer bepaal, aangesien daardie stadium helaas vir ons reeds verlore is. 'n Ontleding van die data deur die Buro vir Statistiek van die M.N.R., waarvoor ons dr. C. van der Merwe hartlik bedank, toon die volgende:

1. 'n Statisties hoogs betekenisvolle korrelasie is gevind tussen die voorkoms van hipertensie en die tydperk van verwestersing. Die tradisioneel lewendes het ' $n$ baie lae bloeddruk, terwyl $21 \%$ van die verwesterse soldate en hul gesinne alreeds hipertensie het. Polstempo, tydens die ondersoek het ' $n$ teenoorgestelde neiging getoon, wat daarop dui dat spanning by die soldategroep nie ' $n$ faktor was nie. Die hoë inname van sout speel moontlik die belangrikste rol by hierdie groep.

2. Die liggaamsmassa-indeks, as maatstaf van obesiteit, toon dieselfde positiewe korrelasie met verwestersing, wat inpas by die kliniese indruk van hipertensie by oormassaswartmense in die stedelike gebiede.

3. Dit was interessant dat die serumcholestrolvlakke nie betekenisvol verskil het tussen die tradisionele en verwesterse groepe nie, ten spyte van die groot verskil in voedsel- en veral vleis- en suiwelinname. Hier word gespekuleer oor die voedingswaarde van die mangettineut, wat die stapelvoedsel van die tradisionele groepe is.'

4. Nog ' $n$ verrassende bevinding was dat die serumnatriumwaardcs van die tradisionele groep hoër was as by die verwesterdes, veral as daar gelet word op hul lae soutinname en normale bloeddrukke.

5. Die kaliumwaardes by die tradisionele groep was daarenteen laag.

6. Serumglukose styg van die tradisionele na die verwesterse groepe, maar die ureum toon 'n teenoorgestelde patroon, terwyl die uraat weer die hoogste is by die verwesterse groep, wat moontlik te wyte is aan die vrye beskikbaarheid van blikkiesbier.

7. Die totale serum, proteien en albumien verskil nie betekenisvol tussen die tradisioneles nie, wat selde en ongereeld vleis, eiers of melk gebruik, en die

- Omegagroep, waar dit volop is. Dit dui op 'n effektiewe proteïeninname uit natuurlike veldkosse. Ons gevolgtrekking is dat verwestersing niks goeds voorspel vir die Boesman se algemene gesondheid en geestelike welsyn nie en dat hul gesonde en sorgvrye dae spoedig iets van die verlede sal wees, aangesien hulle in teenstelling met wat in die wêreldliteratuur beweer word, ook maar vatbaar is vir die siektes wat met verwestersing gepaard gaan.

Ons, as medici, het ongelukkig nooit regtig die Boesman in sy natuurlike staat geken nie, en hierdie waarnemings van ons is, sover ons weet die enigste akkurate biochemiese bepalings wat beskikbaar is. 
Die son sak vinnig oor die eeu-oue kultuur van die Boesman in Suidwes-Afrika en oor 'n unieke geleentheid vir mediese en sosiologiese navorsing, wat spoedig benut behoort te word deur navorsers op hierdie verskillende gebiede.

D.A. van Staden (Direkteur)

P.J. Kloppers

J. Meiring
E. van der Walt

Hans Snyckers-Instituut, Fakulteit Geneeskunde, Universiteit van Pretoria.

\section{VERWYSING:}

1. Wehmeyer, A.S. et al. (1969) The nutrient composition and dietary importance of some vegetable foods eaten by the !Kung Bushmen. S. Afr. Med. J. 43, 1529-1530.

\section{Regstelling}

Jg. 3, no. 3 September 1984, p. 122 1ste reel:

Voeg ,Wetenskapbeplanning” in na „Die Direktoraat”. 